\title{
UWAGI DO „MARGINESU”
}

Mój tekst był poświęcony zmianie znaczeń podstawowych pojęć używanych w badaniach polskiej sztuki współczesnej. Jeżeli z tego względu zwracałem uwagę na kluczową rolę książki Piotra Piotrowskiego Znaczenia modernizmu, to dlatego, że w jego habilitacji z roku 1993 Artysta między rewolucja a reakcja, o którą dopomina się Andrzej Turowski, takiej zmiany nie znajduję. Rozróżnienie między „metafizycznym” a „materialistycznym” biegunem rosyjskiej awangardy dokonuje się w tej książce ciągle w obrębie pojęcia awangardy. A termin „modernizm” pojawia się przelotnie w związku z polemiką Piotrowskiego $z$ Buchlohem zapewne $z$ powodu łatwiejszego nawiązania do argumentacji autora artykułu z pisma "October". Oczywiście, czytelnik nałoży dziś na pojęcie „metafizycznej” awangardy termin „modernizm”. Pojęcia z książki Artysta między rewolucją a reakcją, chociaż nieco inaczej je dzisiaj rozumiemy, absolutnie nie przeszkadzają w odczytaniu intencji autora. Dla mojego wywodu istotne było nie to, do jakich zjawisk odnosiły się terminy, które byśmy dziś zastąpili innymi, ale to, że pojęcie modernizmu w obecnym znaczeniu pojawia się u Piotrowskiego dopiero w roku 1999. A więc w kontekście zupełnie nowej sytuacji artystycznej w Polsce, związanej z kształtowaniem się sztuki krytycznej. Jeżeli Turowski zarzuca mi w związku z tym „polemiczny ferwor”, zwracając uwagę także na to, że od początku lat 90. „lewica i prawica w warunkach wolnego wyboru nabrały właściwego znaczenia" i „mieliśmy do czynienia $z$ inną kontekstualizacją polityczną”, to chętnie na to przystanę, bo to tylko oczywisty, wspierający argument mojego rozpoznania ówczesnego pola sztuki. Czy jednak zagadnienie autonomii i - jak twierdzi Turowski - skierowanie uwagi w stronę badań z wykorzystaniem hermeneutyki czy fenomenologii - miałoby się z tym wiązać? Nie sądzę. Można pewnie spojrzeć na zestaw tłumaczeń w „Artium Quaestiones” czy fundamentalną pracę Mariusza Bryla w perspektywie jakoby skrywanego za nimi ówczesnego politycznego tła, ale myślę, że byłoby to grube uproszczenie.

Pytanie jest jednak inne i tak naprawdę - tak odczytuję głębszy sens wątpliwości Turowskiego - dotyczy zdolności diagnozowania współczesności 
terminami, którymi się dziś posługujemy. Pośrednio dotyczy to także siły porządkującej tych pojęć w uprawianej przez nas historii sztuki. Oczywiście terminy, o jakich pisałem w moim tekście, będą nadal istniały, inercja jest właściwa publicznemu funkcjonowaniu słów, ale czy horyzont wartości, jaki je otacza, ma jeszcze dostateczną siłę sprawczą? Czy „awangarda”, „nowoczesność", „modernizm”, zajmujące pierwsze miejsca w słowniku warsztatu polskiego historyka sztuki współczesnej, są jeszcze przydatne nie tylko w związku z presją nowej humanistyki, ale może przede wszystkim z faktem, że funkcjonujemy „"W warunkach wolnego wyboru” politycznego? I tu książka Artysta między rewolucja a reakcją, o którą dopomina się Turowski, warta jest rozpatrzenia.

Postulat Piotrowskiego etycznej historii sztuki, jaki znajduje się w podtytule publikacji i na ostatnich kartkach książki, łączy "tragedię" rosyjskich awangardzistów z wskazówką dla zachowań współczesnych badaczy. Autor usiłuje znaleźć usprawiedliwienie dla awangardy w niewinnych i "czystych” motywacjach buntu artystów, poprzedzającego toksyczny i manipulatorski związek z sowiecką władzą. To oczywiście za mało, aby uznać niepodważalną wartość estetyczną dzieł awangardy za walor rozstrzygający i wywieść z niego etyczne usprawiedliwienie. Dlatego Piotrowski pisze z pewną dozą patetyczności o "tragedii” i wskazuje na obowiązek rozpoznania rzeczywistości jako ostateczne kryterium oceny wyborów i działań zarówno artysty, jak i obywatela. Jesteśmy w ten sposób w samym centrum oświeceniowej mitologii i awangardowego projektu bezpośrednio się z tej mitologii wywodzącego. To zmitologizowana figura artysty, na którym ciąży misja zmiany świata i rola przewodnika wskazującego cel i przeszkody w jego osiągnięciu. To zmitologizowana, uniwersalna postać władzy, która ze swej natury jest zła, co przypadek Rosji miałby rozstrzygająco potwierdzać. To wreszcie uproszczony, selektywnie odbierany obraz rzeczywistości "społecznej i politycznej praxis”, który Anthony Giddens łączy z właściwą nowoczesności „separacją doświadczenia".

Zacznijmy od "rzeczywistości”. Sugestia przerzucenia pomostu między sytuacją w ówczesnej Rosji a dniem dzisiejszym stawia siłą rzeczy w centrum takich porównań problem nieobecnej w Sowietach demokracji. Czy dzisiejsze wolne wybory w Polsce usuwają problem groźby „tragiczności” decyzji współczesnego artysty? Według Turowskiego, ale i Piotrowskiego - co potwierdzają jego późniejsze teksty - nie, bo nie jest realizowana w praktyce formuła demokracji polemicznej, a charakter władzy jest ze swej istoty stały. Zwrócę jednak uwagę, że zamiast dawnych hamletycznych wyborów awangardowego twórcy, właściwych warunkom totalitaryzmu, mamy dziś inne, bliższe trójkątowi bermudzkiemu, którego pole wyznaczają artysta, władza i opinia publicz- 
na. Problemem współczesnego artysty jest opinia publiczna, równoprawny partner demokratycznego pola, która emancypacyinego (w sensie Giddensowskim, a więc nie wartościującym, a jako projekt oświeceniowej polityki) charakteru działań artysty nie musi akceptować. W krytycznych sytuacjach odwołuje się on do kulturowego immunitetu instytucji wystawienniczych. Jednak decyduje zazwyczaj opinia publiczna i to najczęściej opinia wpływa na rozstrzygnięcia władzy, chcącej powtórnie otrzymać demokratyczny mandat wyborczy, a nie artysta. Nie oceniam tego, tylko przypominam.

Piotrowski próbuje ratować wizerunek awangardy przed dyskwalifikacyjnym, jednostronnym osądem, wynikającym z jej politycznego uwikłania. Argumentem ma być bunt. To pociąga za sobą problem kontekstu społecznego realizacji awangardowych, a na polskim gruncie lat międzywojnia - „nowej sztuki”. Jeżeli wskazałem na utopijne propozycje Szczuki i społecznie paląco potrzebne (i realizowane!) Syrkusa czy Czajkowskiego, to właśnie to miałem na myśli. Piotrowski chce jednak pozycję artysty-buntownika, artysty-utopisty chronić przed weryfikującymi regułami rzeczywistości. Bunt - w perspektywie awangardy - jest wstępnym etapem do realizacji utopii, utopii, której szczególnym modusem jest wyobraźnia. W takim ujęciu reakcją na niedostatecznie rozpoznaną rzeczywistość może być rzeczywiście - sięgam do tekstu Turowskiego - Zolowskie „oskarżam”. Czy jednak bunt i wyobraźnia w proponowanych ujęciach kamienie węgielne awangardy i jej tradycji - mają status zasady wartości? Z czego wywodzi się ich kluczowa rola? Konstytuuje ją uniwersalny charakter autonomii jednostki czy elementarne zasady relacji społecznych? Zacytuję prof. Dorotę Głowacką z publikacji wydawnictwa MOCAK Wielogłos o Zagładzie:

Nie sądzę jednak, aby artyści mieli absolutny immunitet zezwalający im na wszystko, na wpychanie się wszędzie, nawet do komór gazowych, w imię nieograniczonej władzy wyobraźni. Wyobraźnia nie jest bowiem aż tak swobodna, a doświadczenie estetyczne bezinteresowne [...]. Przekonanie o niezmierzonej wolności wyobraźni może się okazać jej największą słabością, gdyż brnąc nieustannie naprzód i przekraczając coraz to nowe granice, nie zastanawia się ona nad tym, co być może ogranicza ją w sposób trudno uchwytny. Wiara w nieskrępowaną moc wyobraźni może być zwodnicza, a nawet niebezpieczna, gdyż z jej powodu przestajemy zastanawiać się nad ramami konceptualnymi, często wyznaczanymi przez uwarunkowania społeczne, historyczne i kulturowe [...].

Sumując: pozaartystyczna rzeczywistość, którą usiłujemy pośrednio sobie przybliżyć stosowanymi przez nas pojęciami, jest o wiele bardziej złożona niż jej obraz, jaki otrzymujemy, posługując się tymi pojęciami. Stąd temat mojego artykułu. Ograniczenia płynące z nieuświadamianych przez nas do końca 
oświeceniowych założeń utrudniają diagnozę i zastosowanie nowych badawczych narzędzi. Stąd postulaty w końcowej partii mojego tekstu. Dobrze jest być tak pewnym, jak zawiera to bieżący druk innego muzeum sztuki współczesnej: „Tylko podmioty niezależne w myśleniu, takie, które wydostały się ze stanu intelektualnej niedojrzałości, są w stanie wziąć pełną odpowiedzialność za siebie i świat". Ja takiej pewności nie mam, ale rozumiem sprzeciw Andrzeja Turowskiego, mówimy wszak o różnych koncepcjach podmiotu. 